\title{
What Was the Impact of Zionism on Displaced Jewish Refugees in Germany in the Aftermath of the Second World War?
}

\author{
Francesco Bruno \\ Humanitarian and Conflict Response Institute \\ Master of Arts in Peace and Conflict Studies, UK
}

Received: Jul. 29, 2018 Accepted: Nov. 12, 2018 Online published: Nov. 18, 2018

doi:10.5296/jpag.v8i4.13931～URL: https://doi.org/10.5296/jpag.v8i4.13931

\begin{abstract}
This paper explores the birth of the state of Israel with particular emphasis on the role of the Zionist ideology. Zionism as an ideology can be seen not only as a singular ideological view, but as a confluence of multiple ideas that trace back to the 19th century and even earlier to the diaspora of the Jewish people. The final product of the Zionist idea is the state of Israel. Great emphasis in this paper Is given to the role of Zionism after the end of World War II, which saw the mass murder of over 6 million Jewish. Zionism posed the dilemma to the Jewish people in the following terms: the creation of a state where Jewish people could have been represented as the majority with their own rules and legislation and the complete assimilation within other countries. In other words, Zionism aimed to give the Jewish people a nationalistic identity and remains a strong factor that influenced the Jewish people within the DP camps in the aftermath of the Second World conflict. The paper begins with the analysis of Zionism as an ideology from the 19th century onward and the conditions of the Jewish people in the aftermath of World War II. These two points are then analysed to demonstrate two main points. The first is the resiliency and adaptability of the Zionist ideology as the only way forward for the Jewish people and second, the status of the Jewish people as "victims" and this idea gave them the freedom to approach the creation of a new society with a general "benevolence" from the international community.
\end{abstract}

Keywords: World War II, Zionism, Jewish people, Israel, UNRRA, nationalism

\section{Introduction}

The history of the immigration to Israel has become an essential topic to discuss multiple issues which are related to this phenomenon. This paper will argue that Zionism became the only available answer to the Jewish situation in the aftermath of the Second World War. It 
will assess the role of Zionism and how it became the juncture between the present and past of the Jewish people. In this sense, the paper will assess how the multiple ideologies which are assimilated by Zionism aim to unify a population that is de facto spread across the world and has, therefore, multiple issues of adaptation which clash with their identity as Jewish people. The paper will point out the nature of Zionism as a movement which saw the primary role played by Western ideologies. In this sense, the State of Israel can be seen as the final product of the Zionist ideology which slowly defined itself through the nineteenth century until the foundation of Eretz- Yisrael in 1948. This paper will focus on the remaking of the consciousness of being Jewish in the displaced persons (DP) camps in the aftermath of the Second World War and will highlight how alternatives such as 'integration' would have meant the end of Jewish society and its culture. The paper is divided in two segments, the first of which will highlight the role, the ideas, and the history of the Zionist movement. The second will examine the factors that allowed the Jewish people to form the She'erith Hapletah which strongly promoted a nationalist idea in connection to the Zionist ideology. The importance of UNRRA to regroup displaced people in camps based on shared ethnicity and the migration of over 250,000 Jews from Eastern Europe to the American controlled-areas became an opportunity for the Jews to recreate their self-image as a mix between traditional communitarian elements and national conceptions. In this context, the impact of Zionism can be seen as a driving and decisive factor allowing the creation of a vibrant nationalist society within the DP camps.

\section{Zionism an Ideology of Many Ideologies}

The first part of the paper will focus on the essence of Zionism as ideological movement. The Zionist ideology, first articulated by the Hibbat Zion movement at the end of the $19^{\text {th }}$ Century, is based on the 'idea of return to Zion and its restoration as a homeland for the Jews that not only transcended the messianic idea but also produced extensive social results and a continuous ideological development'. 'Shimoni argues that 'the situation of the Jews within the majority societies of their domicile prior to the nineteenth century process of Jewish emancipation was in many significant respects like that of colonized peoples all over the world. That is to say, the Jews were 'subaltern' victims, subject to various forms of domination by the majority society, not least of them being a hegemonic cultural discourse that represented Jews as the quintessential Oriental Other'. ${ }^{2}$ In this sense, Shimoni argues that the nature of Zionism as Jewish identity is to be attributed to the "radical identity transformation that led them to refuse integration and assimilation, and, instead to assume leadership roles in propelling Jewish ethnic-self affirmation toward fully fledged nationalism in the form of Zionism'. ${ }^{3}$ Similarly, Cohen's analysis of Theodore Herzl's letters, testify that Herzl was painfully affected by the experience of Jewish individuals in European societies; for instance, he describes 'the event in Mainz while travelling through Germany in 1888,

\footnotetext{
${ }^{1}$ Shimoni, Gideon.( 1995). The Zionist Ideology. (1st ed.). Hanover: Published by University Press of New England [for] Brandeis University Press. p.85

${ }^{2}$ Kelmar and Penslar(eds) Orientalism and the Jews, MA Waltham, London 2005 cited in Shimoni, Gideon (2007) Postcolonial Theory and the History of Zionism, Israel Affairs, 13:4, 859-871, DOI: 10.1080/13537120701445331 available at: http://dx.doi.org/10.1080/13537120701445331 p.860

${ }^{3}$ Shimoni, Gideon(2007) Postcolonial Theory and the History of Zionism p.862
} 
when he entered a cheap music-hall to drink a glass of beer, and, when he rose to leave and make his way through the noise and smoke to the door, he heard a youth call out: "'Hep Hep", which means 'Hierosolyma est perdita' (Jerusalem is lost)'. ${ }^{4}$ Most of all, Cohen describes Herzl's painful experience with the French army captain Alfred Dreyfus (1859-1935), who was falsely accused of high treason and condemned to imprisonment for life. Herzl says that 'the Dreyfus case was not merely a judicial error: it demonstrated the wish of the majority in France to condemn all Jews just because of one'. 5 Similarly, he continues saying that 'it had hitherto generally been believed that the solution of the Jewish question would result from the gradual evolution of humanity to a state of toleration. But if such a highly civilized people as the French could sink to such depths of iniquitous injustice, what could be expected from other nations that had not yet progressed as far as the French had a century before? ${ }^{6}$ In this sense, Theodore Herzl concluded that 'the best solution of the Jewish question would consist in the Jews enjoying national independence in a land of their own'. The result of Herzl's thought became the creation of an ideology which 'strives to normalize the status of the Jewish people by achieving political sovereignty' while 'reflecting the late nineteenth century European ideologies of nationalism, socialism, liberal democracy' ${ }^{8}$ In its most basic form, Zionism believes that the Jewish people share a single and distinctive identity with specific national and religious attributes. As ideology, it has been the subject of numerous ramifications and developments, although it is possible to highlight three essential principles that are commonly accepted by the multiple strains of Zionism. Firstly, 'the situation of the Jewish entity under conditions of dispersion is critically defective, not just in a messianic sense but emphatically in a worldly sense; secondly, the solution lies in territorial ingathering of Jews in Eretz-Yisrael under conditions of autonomy at least and sovereignty at best; thirdly, these purposes should be effected by political diplomacy, settlement activities, and the revival of Jewish morale and culture'. ${ }^{9}$ One interesting point to analyse is the metamorphosis that Zionism was subjected to between 1914 and 1933. In this context, the role of Berkowitz's analysis becomes essential. He says that 'Zionism became a compartmentalized variant of Jewish ethnic identification and a basis for local and international Jewish solidarity and sociability - and obviously, politics'. ${ }^{10}$ Western Zionism became the emblem of 'strength, self-reliance and honor' in support of a population who have been long victimized internationally. In this sense, Zionism became the tool for 'telling the Jews that they were simultaneously cursed and blessed by their distinctiveness as a nation'. ${ }^{11}$ In Europe and America, Zionism came to support the soldiers who fought across Europe and in Palestine and to represent them as heroes. In this sense, the war incorporated into the movement a sense of strong militarism that reflected the glorification of what Berkowitz calls 'the Jewish

\footnotetext{
${ }^{4}$ Cohen, Israel. (1959). Theodor Herzl, Founder Of Political Zionism. 1st ed. New York: T. Yoseloff, p.63

${ }^{5}$ Cohen, Israel. (1959). Theodor Herzl, Founder of Political Zionism p. 66

${ }^{6}$ Ibid .p67

${ }^{7}$ Ibid p.67

8 Dowty, Alan. (1998). The Jewish State. 1st ed. Berkeley: University of California Press. p.34

${ }^{9}$ Shimoni, Gideon. (1995). The Zionist Ideology p. 85

${ }^{10}$ Berkowitz, Michael. (1997). Western Jewry and the Zionist Project, 1914-1933. 1st ed. Cambridge: Cambridge University Press. p.196

${ }^{11}$ Berkowitz, Michael. (1997). Western Jewry and the Zionist Project, 1914-1933 p.197
} 
Legion' that fought with the allies to free Palestine from the Turks as the representation par excellence of Jewish heroism. ${ }^{12}$ The movement represented these soldiers as heroes in order to reinforce the idea that the Jewish people share not only a strong national identity, but also a sense of patriotic unity and bravery recognized around the world. In this sense, the Jews would feel proud of their heritage and related to each other by their origins.

Recalling Dowty, it is possible to highlight the deep influence that the European Enlightenment and Western ideologies had over Zionist ideology. The first and most dominant idea was Nationalism; Harold Fisch says, talking about the Nationalistic component of the Zionist movement, that 'the two dominant impulses in the Return to Zion are obligation and love; an obligation which holds one even when the land appears bleak and inhospitable and when hostile strangers dwell in it, and a love for which the only proper analogy is the love of the bridegroom for the bride'. ${ }^{13}$ Nationalism has had a profound impact on the Zionist ideology and its international appeal; Shimoni recalls Smith's term 'ethnic' to describe the connection between ethnicity and nationalism that forms the basis of the Jewish ethnic nationalism embedded in Zionism. ${ }^{14}$ In proclaiming that the Jews share a single national identity and that this identity is related to a specific land in which to found a fully independent state, Dowty argues that 'the Jews moved from a more particularistic framework, if not their exclusive connotations and place in the world to a more universal and common model' ${ }^{15}$ In this sense, Dowty argues that the movement towards the creation of a physical entity would become the foundations from which the Jews would be able to enjoy the principles of self-determination and reciprocal respects among nations. In the $20^{\text {th }}$ century, the Zionist nationalistic view became more particularistic, asserting that the 'exclusive right of the Jewish people to all of Eretz- Yisrael, condemned any 'compromise' of this right'. ${ }^{16}$ The second component is the Socialist one, also called Labor Zionism. Its role was integrated into the Zionist ideology due to its appealing aspects concerning 'social justice, a conception of ultimate deliverance (messianism), perception of a basically hostile environment, and justification of revolt against established authority'. ${ }^{17}$ On the one hand, the socialist component of the Zionist ideology became essential in revitalizing the Jewish traditions of communitarianism which have historically been strictly connected to the preservation of Jewish culture and customs. On the other hand, the Socialist component was used to create a common identity for Jews living in different states and in different socio-economic and political conditions. In this sense, the Socialist component became the instrument for denouncing their socio-political hardships. Herzberg expresses this concept, arguing that Socialism became the connecting dot for 'the united road for all the Jews who are being forced to migrate, to pave the poor driven by need, for refined Jews stung by insults, and for romantic and religious Jews who bewail the deterioration of the people and the destruction of the Temple; to give a rational purpose to all those who feel the pain of the Exile; and to

\footnotetext{
${ }^{12}$ Ibid. p.20-21

${ }^{13}$ Fisch, Harold. (1978). The Zionist Revolution. 1st ed. London: Weidenfeld and Nicolson.p.21

${ }^{14}$ Smith,(1971) Theories of Nationalism p. 255 cited in Shimoni, Gideon. 1995. The Zionist Ideology p.12

${ }^{15}$ Dowty, Alan. 1998. The Jewish State p.36

${ }^{16}$ Ibid. p.37

${ }^{17}$ Ibid. p.38
} 
raise their individual protest to the level of a general moral resistance aimed at the rebuilding of Jewish life - that is the purpose of Zionism, a movement inevitably born of Jewish sufferings which has encompassed all segments of Jewry'. ${ }^{18}$ The third component of Zionism is Liberalism. In this sense, Liberalism can be associated with those groups within the Zionist movement known as General Zionism. General Zionism was made of all of those groups that did not feel any associations with the other strains of the Zionist movement, namely Religious-Nationalist and Socialist. In this sense, Shimoni argues that Liberalism 'begins with the fundamental value of individual liberty, maximizes such liberties, champions the autonomy of the individual and is wary of the powers of the state'. ${ }^{19}$ In the specific context of Zionism, Liberal ideas 'were concerned with the protection against adulteration with extraneous value systems, particularly socialism of the type that advocated class warfare and hostility toward private enterprise'. ${ }^{20}$ Similarly, Liberal ideas have also supported the common trait of what Shimoni calls "the primacy of the nation' reinforcing the allegiance to the nation as a function of organic ethnic kinship and that the individual's life could be considered meaningful only through the prism of the nation'. ${ }^{21}$ Similarly, Western Liberalism has also influenced two main aspects of the Zionist ideas: first, the juridical and legal branches were influenced by the Western heritage, especially British and American; and second, the economic sphere and the democratic values were reinforced and adopted in response to the socialist supporters. ${ }^{22}$

\section{The Jewish People after the End of World War II}

The second part of this paper will be based on the analysis of the living conditions of the Jewish people in the aftermath of the Second World War. This section will highlight that Jewish people were forcefully categorized as displaced people and that the environment created by the Second World War and the Nazi persecutions, in conjunction with their socio-political situation related to their Jewish identity, consequently became the platform for the quick spread of Zionism and the resultant mass migration to Palestine. In this sense, the resilient and international nature of the Zionist movement described in the previous section has had a pivotal impact on those European Jews who felt internationally isolated and unable to see any positive outcome in the foreseeable future. The end of the Second World War had left a massive quantity of refugees and displaced people in Germany, Italy and Austria. Mankowitz suggests that at the end of the Second World War, there were around ' 11 million of Germans and people of German descent' while the chaotic situation increased quickly with DPs leaving Germany at the rate of 60,000 to 80,000 a day'. ${ }^{23}$ However the situation was even more catastrophic for the Jewish population due to the fact that 'over six million Jews more than one-third of world Jewry - had lost their lives in Nazi Europe. They could not return to their homes from which they had been driven by the Nazis and the non-Jews who,

\footnotetext{
${ }^{18}$ Hertzberg, Arthur. (1972). The Zionist Idea. (1 st ed.). New York: Atheneum. p.347

${ }^{19}$ Shimoni, Gideon. (1995). The Zionist Ideology p.121

${ }^{20}$ Ibid. p. 121

${ }^{21}$ Ibid. p. 121

${ }^{22}$ Dowty, Alan. (1998). The Jewish State p.40

${ }^{23}$ Mankowitz, Zeev W. (2002). Life between Memory and Hope. 1st ed. New York: Cambridge

University Press. p.12
} 
with the blessings of their Nazi overlords, had taken over the possessions of the Jews were alarmed at the prospect of having to make restitution'. ${ }^{24}$ Similarly, the phenomenon of anti-Semitism remained a pivotal issue for the Jewish people in Germany, Bokser continues, saying that "when these surviving Jews who, scarred body and mind, returned to their homes in search of their possessions and families, they found the atmosphere about them poisoned with hatred and resentment'. ${ }^{25}$ On the same track, the intention behind the persecutions against the Jews was not only related to material things, but it focused on the annihilation of a specific cultural heritage. Kolinsky argues that the 'Holocaust itself had destroyed the meaning of community which has historically been the fundamental basis for the formulation and creation of the Jewish culture and society'. ${ }^{26}$ In this context, an important connotation to be highlighted is what Weitz describes as 'the image of passivity that portrayed survivors as broken and helpless, ground to dust by unspeakable torture' who became known as 'walking skeletons'. ${ }^{27}$ This image of passivity was then related to their international status as displaced population and became symbolic. Cohen argues that 'Jews were not merely perceived as 'war victims' deserving of humanitarian relief but also as unique targets of racial and political persecution warranting historical recognition; unlike other post-war victims, Jewish refugees were acknowledged as paradigmatic victims entitled to specific migratory and 'resettlement' claims'. ${ }^{28}$ These conditions became propaedeutic for the promoting of international recognition that ultimately favoured the nationalization of the Jews into one single people and entitled to self-determination. ${ }^{29}$ In this sense, the Jews were able to move to camps where the majority of the population was Jewish and this helped to nationalize their status, as well as socio-political situation, in what became known as She'erith Hapletah (the Surviving Remnant). These large communities included 50,000 to 60,000 Jews who shared the experience of the Holocaust together with another 200,000 - 250,000 Jewish 'infiltrees' coming from Eastern Europe, especially Polish ones exiled by the Soviet Union during the war and repatriated in $1945-1946 .{ }^{30}$ Cohen argues that 'the acceptance of these Jewish refugees coming from Eastern Europe in the American and British areas under what the United Nations Relief and Rehabilitation Administration (UNRRA) calls "internal displacement", was not due to their displaced status or their country of origins, but rather as an acknowledged national entity with precise migratory claims' which were added to the already vibrant Zionist politics in the camps. ${ }^{31}$ Cohen's analysis brought him to argue that

\footnotetext{
${ }^{24}$ Bokser, Ben Zion. (1973). Jews, Judaism, and the State of Israel. 1st ed. New York: Herzl Press. p.209

${ }^{25}$ Bokser, Ben Zion. (1973). Jews, Judaism, and the State of Israel p.209

${ }^{26}$ Kolinsky, Eva.( 2004). After the Holocaust. 1st ed. London: Pimlico.p. 136

${ }^{27}$ Weitz Y., The yishuv and she'erith hapletah 1944-1945 p.8 and 59 cited in Mankowitz, Zeev W. (2002). Life between Memory and Hope p.7

${ }^{28}$ Cohen, Gerard Daniel (2006) The Politics of Recognition: Jewish Refugees in Relief Policies and Human Rights Debates, 1945 - 1950, Immigrants \& Minorities, 24:2, 125 - 143, DOI:

10/1080/02619280600863572 available at: http://dx.doi.org/10/1080/02619280600863572 p.128

${ }^{29}$ Cohen, Gerard Daniel (2006) The Politics of Recognition: Jewish Refugees in Relief Policies and Human Rights Debates, 1945 - 1950 p.128-129

${ }^{30}$ Cohen, Gerard Daniel (2006) The Politics of Recognition: Jewish Refugees in Relief Policies and Human Rights Debates, 1945 - 1950 p.126

31 Cohen, G. D. 2008. "Between Relief and Politics: Refugee Humanitarianism in Occupied Germany
} 
the nationalization of the Jewish people which took place in Germany, and that spread across the camps and became a pivotal movement towards the Zionist ideology, was caused by the creation of large mono-ethnic communities that included Jewish people of multiple backgrounds and nationalities who saw in the Zionist movement the only chance to escape their ineluctable destiny of 'being Jewish'. Their individual experiences became collectivized in these DPs camps, and in this respect Ouzan argues that 'the cultural and social life of the Jewish groups integrated both aspects of the traditional Jewish culture and the Zionist-nationalistic aspects. As a result, a new Jewish nationalistic culture emerged both from the memory of the Shoah and from "nationalistic" lessons "rooted in the Jewish biblical tradition" amplified by the Zionist ideology'. ${ }^{32}$ In this communal life were posed the basis for 'the general reaffirmation of the primacy of the nation-state as well as repatriation policies redefined the bonds of citizenship in liberated Europe'. ${ }^{33}$ This transformation toward nationalization, in connection with the general willingness for Jewish 'self-determination, became the pivotal element for their 'identity renewal'. In this context, the Zionist movement was able to 'convert' these displaced people and refugees to its cause through the development of a capable program 'that seemed to make sense after the catastrophe... Without Palestine there seemed to be no future for the Jewish people'. ${ }^{34}$ In this sense, despite 'anti-Zionist resistance or even neutral attitude toward the movement, the Jewish people in Germany saw it as a threat to the most fundamental stakes in their future', namely the right to exist as Jewish people. ${ }^{35}$

\section{Summary}

To sum up, this paper has tried to point out the role of the Zionist ideology in the nationalization which took place in the refugee camps in Germany in the aftermath of the Second World War. The paper has been divided in two sections; the first is related to the definition of Zionism given by its founder, Theodore Herzl at the end of the $19^{\text {th }}$ century. Zionism as ideology sought to affirm the principle that the Jewish people are a single people and that they deserve their right to self-determination to preserve their culture and heritage. In defining the Zionist ideology, there are three main ideologies which have influenced it: Nationalism as the driving ideology for the preservation of Jewish life in the community, the cultural heritage and religion ideas; Socialism as the ideology that drives individual freedoms and emancipation; and finally, Liberalism as the driving ideology that came from the British and American influence in the $19^{\text {th }}$ and $20^{\text {th }}$ centuries. In this context, liberalism has therefore perpetuated the existence and reinforcement of the Democratic values while placing particular emphasis on the attachment to the nation. The second part of the paper has then

1945--1946". Journal of Contemporary History 43 (3): 437-449. doi:10.1177/0022009408091834: pp.448-449

32 Ouzan Francoise, Rebuilding Jewish identities in Displaced Persons Camps in Germany, Bulletin du Centre de recherche francais à Jérusalem[Online], 14/2004, Online since 10 October 2007, connection on 30 September 2016. URL: http://bcrfj.revues.org/269 p.109

33 Cohen, G. D. (2008). "Between Relief and Politics: Refugee Humanitarianism in Occupied Germany 1945--1946". p.134-135

${ }^{34}$ Mankowitz, Zeev W. (2002). Life between Memory and Hope p.213

${ }^{35}$ Ibid. p. 213 
outlined the situation for the Jews in the aftermath of the Second World War in order to point out that the Zionist ideology was embraced quickly and by the majority of the population, regardless of their socio-political or economic situation, due to the fundamental issue that the Jewish way of life was under threat of extinction. Overall, international isolation - together with the willingness to allow the Jewish people to be entitled to self-determination in conjunction with the spread of the Zionist ideology when a high number of Jewish people moved from Eastern Europe into the American and British zones thereby creating mono-ethnic Jewish communities who shared their lives' experiences of before, during and after the war - led to an embracing of the Zionist ideology as the only way to escape the basic threat to their existence as Jewish people through the elimination of Jewish culture.

\section{Conclusion}

In conclusion, the paper has highlighted two main points: the resiliency of the Zionist ideology to promote itself as the main project and the necessity for the refugees to find a way out of a situation that did not offer the prospect of any possible satisfactory outcome in the foreseeable future. The international recognition that allowed the Jewish people to embrace self-determinism was, therefore, the consequence of the quick expansion of the Zionist ideology among displaced Jewish people and refugees who took the occasion to prepare to emigrate for Palestine, where the Zionist propaganda and heroism of Jewish legions and soldiers had sought to re-establish the pride of the Jewish identity. In this context, the need for normalization of their communal and individual lives, in connection with the international recognition that the Jewish people are entitled to the right to determine their own destiny, have become the driving factors for the massive migration to Eretz-Yisrael prior to the foundation of the State of Israel in 1948. Zionism was therefore able to concretely advance the possibility of ensuring that the Jewish identity could be preserved and protected against integrational policies that had affected Jewish lives for centuries In a situation in which international isolation and the threat of cultural disappearance through integration had created deep scars in the Jewish identity, the proposal for national renewal and self-determination made possible the migration to Palestine and the consequent foundation of the State of Israel.

\section{Acknowledgment}

This paper would not have been possible without the continuous support of my family as well as my personal interest in the culture of Nationalism that makes us all feel part of something bigger. Putting in George Eliot's words: "A human life, I think, should be well rooted in some spot of a native land, where it may get the love of tender kinship for the face of the earth, for the labours men go forth to, for the sounds and accents that haunt it, for whatever will give that early home a familiar unmistakable difference amidst the future widening of knowledge: a spot where the definiteness of early memories may be inwrought with affection, and kindly acquaintance with all neighbours, even to the dogs and donkeys, may spread not by sentimental effort and reflection, but as a sweet habit of the blood. [...]The best introduction to astronomy is to think of the nightly heavens as a little lot of stars belonging to one's own homestead." 


\section{Reference}

Berkowitz, M. (2002). Western Jewry and the Zionist project, 1914-1933. Cambridge: Cambridge University Press.

Bokser, B. (1973). Jews, Judaism and the State of Israel. New York: Herzl Press.

Cohen, G. (2006). The Politics of Recognition: Jewish Refugees in Relief Policies and Human Rights Debates, 1945 - 1950, Immigrants \& Minorities, 24:2, 125 - 143. Retrieved from http://dx.doi.org/10/1080/02619280600863572

Cohen, G. (2008). Between Relief and Politics: Refugee Humanitarianism in Occupied Germany 1945-1946. Journal Of Contemporary History, 43(3), 437-449. https://doi.org/10.1177/0022009408091834

Cohen, I. (1959). Theodor Herzl, founder of political Zionism. New York, London: New York: T. Yoseloff..

Dowty, A. (1998). The Jewish state. $\left(1^{\text {st }}\right.$ ed.).Berkeley: University of California Press

Fisch, H. (1978). The Zionist Revolution, London: Weidenfeld and Nicolson.

Hertzberg, A. (1972). The Zionist Idea. (1st ed.). New York: Atheneum.

Kolinsky, E. (2004). After the Holocaust. (1st ed.). London: Pimlico.

Mankowitz, Z. (2007). Life between memory and hope (1st ed.). Cambridge: Cambridge University Press.

Ouzan, F. (2004), Rebuilding Jewish identities in Displaced Persons Camps in Germany, Bulletin du Centre de recherche francais à Jérusalem[Online], Online since 10 October 2007, URL: http://bcrfj.revues.org/269

Shimoni, G. (1995). The Zionist Ideology. (1st ed.). Hanover: Published by University Press of New England [for] Brandeis University Press.

Shimoni, G. (2007). Postcolonial Theory and the History of Zionism. Israel Affairs, 13(4), 859-871. https://doi.org/10.1080/13537120701445331

\section{Suggested readings}

Alroey, G. (2011). “Zionism without Zion?” Territorialist Ideology and the Zionist Movement, 1882 - 1956, Jewish Social Studies, 18(1), 1-32. https://doi.org/10.2979/jewisocistud.18.1.1

Baumel, J. (1995). Kibbutz Buchenwald and Kibbutz Hafetz Hayyim: Two Experiments in the Rehabilitation of Jewish Survivors in Germany. Holocaust And Genocide Studies, 9(2), 231-249. https://doi.org/10.1093/hgs/9.2.231

Baumel, J. (2006). Bridging myth and reality: the absorption of She'erit Hapletah in Eretz Yisrael, 1945-48. https://doi.org/10.1080/00263209708701157

Gibbs, R. (2010). The Jewish Tradition. A Companion To Philosophy Of Religion, 210-216. 
https://doi.org/10.1002/9781444320152.ch23

Herzl, T., Bein, A., \& Lipsky, L. (1946). The Jewish State. An attempt at a modern solution of the Jewish question. Biography, based on the work of A. Bein. Introd. by L. Lipsky (1st ed.). [New York]: American zionist emergency Council.

Schwartz, D. (2000). The Revolutionary Consciousness of the Religious Zionist Movement Since 1902. Review of Rabbinic Judaism, 3(1), 175-184. https://doi.org/10.1163/157007000X00073

\section{Copyright Disclaimer}

Copyright for this article is retained by the author(s), with first publication rights granted to the journal.

This is an open-access article distributed under the terms and conditions of the Creative Commons Attribution license (http://creativecommons.org/licenses/by/4.0/). 